\title{
Cell-specificity of transforming growth factor- $\beta$ response is dictated by receptor bioavailability
}

\author{
Magdalena I Suszko ${ }^{1}$ and Teresa K Woodruff ${ }^{1,2}$ \\ ${ }^{1}$ Department of Neurobiology and Physiology, Northwestern University, 2205 Tech Drive, Evanston, Illinois 60208, USA \\ ${ }^{2}$ Department of Medicine, Northwestern Medical School, Chicago, Illinois 60611, USA \\ (Requests for offprints should be addressed to T K Woodruff; Email: tkw@northwestern.edu)
}

\begin{abstract}
Members of the transforming growth factor- $\beta$ (TGF $\beta$ ) family control diverse cellular responses including differentiation, proliferation, controlled cell death and migration. The response of a cell to an individual ligand is highly restricted yet the signaling pathways for TGF $\beta$, activin and bone morphogenic proteins share a limited number of receptors and activate similar intracellular cytoplasmic co-regulators, Smads. A central question in the study of this family of ligands is how cells titrate and integrate each TGF $\beta$-like signal in order to respond in a cell- and ligand-specific manner. This study uses the pituitary gonadotrope cell line, L $\beta$ T2, as a model to delineate the relative contribution of TGF $\beta$ and activin ligands to follicle-stimulating hormone (FSH) biosynthesis. It was found that pituitary gonadotrope cells do not express the TGF $\beta$ type II (T $\beta$ RII) receptor and are therefore not responsive to the TGF $\beta$ ligand. Transfection of the receptor restores TGF $\beta$ signaling capabilities and the TGF $\beta$-mediated stimulation of FSH $\beta$ gene transcription in L $\beta$ T2 cells. Consequently, we evaluated the presence of the T $\beta$ RII in the adult mouse pituitary. T $\beta$ RII does not co-localize with FSH-producing cells; however it is detected on the cell surface of prolactin- and growth hormone-positive cells. Taken together, these results suggest that the bioavailability of the TGF $\beta$-specific receptor rather than TGF $\beta$ dictates pituitary gonadotrope selectivity to activin, which is necessary to maintain normal reproductive function. It is likely that the ligand-restricted mechanisms employed by the gonadotrope are present in other cells, which could explain the distinct control of many cellular processes by members of the TGF $\beta$ superfamily.
\end{abstract}

Journal of Molecular Endocrinology (2006) 36, 591-600

\section{Introduction}

The ability of a single cell to respond to a particular cue is vital for normal function and survival of all organisms. As transforming growth factor- $\beta$ (TGF $\beta$ ) ligands control a variety of cellular responses, cells are constantly challenged by signals from multiple members of the superfamily. These ligands are key regulators of cell development, differentiation and proliferation, as well as migration and apoptosis. To date, 42 members of the TGF $\beta$ superfamily have been identified in the human genome and, based on a sequence similarity, two subfamilies of TGF $\beta$-related proteins have been delineated. In addition to the TGF $\beta /$ activin/nodal subgroup, a bone morphogenic protein/growth and differentiation factors/Mullerian inhibiting substance (BMP/GDF/MIS) subfamily has been characterized. Interestingly, the diverse TGF $\beta$ ligands signal through a limited number of receptors and intracellular signaling proteins to elicit different cellular responses.

There are five type II and seven type I serine/ threonine kinase receptors available for initiation of the TGF $\beta$ signaling cascade. Ligand-activated receptors phosphorylate receptor-restricted Smad (R-Smad) pro- teins, which results in a propagation of the downstream intracellular signal. There are only five R-Smads that have been identified in mammals and, by convention, they fall into two groups based on their association with a particular TGF $\beta$ subfamily (reviewed in Shi \& Massague 2003). It is intriguing that, given a limited number of available receptors and Smad molecules, the cell can still sense and respond to each ligand in a very precise manner.

A variety of mechanisms have been implicated in the tight control of cellular responses to the members of the TGF $\beta$ superfamily. The most obvious way of regulating ligand function is its spatial and temporal bioavailability. During Xenopus development, an increasing dose of activin leads to the sequential transcription of Xenopus brachyury (Xbra) mesoderm gene, which is followed by expression of goosecoid (gsc) and eomesodermin (eomes) genes (reviewed in Gurdon \& Bourillot 2001). Another way of limiting ligand activity is through the expression of a bioneutralizing protein. Several high-affinity binding proteins have been identified for the TGF $\beta$ superfamily. These factors include follistatin, noggin, chordin/SOG, and proteins of the DAN family (reviewed in Bernard et al. 2001, Shi \& Massague 2003, Zwijsen et al. 2003). 
While these molecules can antagonize effects of the TGF $\beta$ ligands through direct binding, inhibin blocks activin action by sequestering the activin receptors (Lewis et al. 2000, Chapman \& Woodruff 2001). This regulatory mechanism controls ligand access to receptors and requires membrane-anchored proteins that act as co-receptors, such as betaglycan, cripto and endoglin. Thus, this constitutes an important way of regulating ligand-specific responses in a cell- and tissue-specific manner.

In addition, receptor availability and activity in general can influence a particular pathway. In fact, receptor interactions at the level of the plasma membrane have been implicated as an important mechanism for the regulation of TGF $\beta$ signaling events. The type I TGF $\beta$ receptor has been found associated with cholesterol-rich membrane microdomains, known as caveolae, and this receptor positioning within a membrane suppresses TGF $\beta$-mediated phosphorylation of Smad2. Conversly, ligand-bound TGF $\beta$ receptors can undergo endocytosis to early endosomes, where they phosphorylate Smads (Razani et al. 2001, Lu et al. 2002). The activity of receptors and, more importantly, the duration of their active state is also crucial for facilitating a particular cellular response. Receptor activity is required to maintain active Smad complexes in the nucleus and directly reflects the level of the specific signal up to the point of saturation and desensitization of the receptor complex.

In the reproductive axis, activin is essential for the biosynthesis of follicle-stimulating hormone (FSH) $\beta$. This regulation is specific to the anterior pituitary gonadotrope cells, where locally produced activin directly stimulates FSH production. Activity of this ligand is reduced by both follistatin and inhibin. Interestingly, both activin and inhibin share a number of their signaling components with a transduction cascade initiated by the TGF $\beta$ ligand. For example, both TGF $\beta$ and activin signal via the intracellular mediators, Smad2 and Smad3. In addition, both inhibin antagonism of activin action and TGF $\beta$ signaling require the co-receptor betaglycan (Lewis et al. 2000, Chapman \& Woodruff 2001). Therefore, it became important to determine the relative contribution of these ligands to FSH biosynthesis and to delineate the gonadotroperestricted TGF $\beta$ superfamily signaling pathways.

This report addresses essential questions regarding the ability of the pituitary gonadotrope to titrate and integrate different TGF $\beta$ signals. Characterization of processes by which the cell manages a discrete response, such as a precise FSH surge, is necessary for the understanding of normal cell function. These data demonstrate that one of the mechanisms that can regulate cell-specific responses is receptor bioavailability. More importantly, the data reveal that the gonadotrope cells are unable to discriminate between signaling pathways initiated by activin and the TGF $\beta$ receptor complex. In the light of these findings, receptor assembly, activation and desensitization become even more critical as a mechanism of regulating diverse cellular responses to TGF $\beta$ ligands.

\section{Materials and methods}

\section{Recombinant ligands}

Recombinant human (rh) activin A (activin) was produced in our laboratory (Pangas \& Woodruff 2002). TGF $\beta 1$ ligand was purchased from R\&D Systems, Inc. (Minneapolis, MN, USA).

\section{DNA constructs, cell culture and transient transfections}

Reporter construct containing the rat FSH $\beta$ promoter gene fused to the luciferase reporter gene in the pXP2 $\Delta 2$ vector (described previously by Suszko et al. 2003) and the p3TP-Lux reporter plasmid were provided by Dr J Massagué's laboratory. Constitutively active receptor (CA-ALK4 and CA-ALK5) expression vectors were a generous gift of Dr Y Chen and have been described previously (Chen et al. 1997, Nagarajan \& Chen 2000).

The pituitary gonadotrope cell line, L $\beta \mathrm{T} 2$, was carried on plates coated with matrigel (BD Biosciences, Bedford, MA, USA) in F12:DMEM supplemented with $5 \%$ fetal bovine serum (FBS), $0 \cdot 45 \%$ glucose and $1 \%$ antibiotic and kept in a humidified atmosphere $\left(37^{\circ} \mathrm{C}\right)$ of $5 \% \mathrm{CO}_{2}$. All transfections and experimental treatments have been described before (Suszko et al. 2003). Briefly, cells were plated one day before transfection in 24-well plates and transfected with $250 \mathrm{ng}$ of the reporter DNA, $25 \mathrm{ng}$ of the expression vector and $50 \mathrm{nM}$ of the indicated small interfering (si) RNA oligoduplexes (Dharmacon, Inc. Lafayette, CO, USA) per well using Lipofectamine 2000 (Invitrogen, Carlsbad, CA, USA). Empty vectors were used to balance DNA where necessary. Cells were treated with control media or appropriate ligands in phenol-free, serum-free F12:DMEM (Invitrogen). We attempted to utilize internal controls for all transfection experiments by dual luciferase and $\beta$-galactosidase assays. Unfortunately, co-transfection of both renilla-luciferase and $\beta$-galactosidase expression vectors caused a significant decrease in activin response. L $\beta$ T2 cells were grown on a matrigel matrix, which interfered with normalization of luciferase activity to protein content. The data shown here reflect the mean fold over control of multiple repeatable transfection experiments.

\section{Rat primary pituitary cell culture and radioimmunoassay}

All animals were treated in full accordance with the NIH Guide for the Care and Use of Laboratory Animals. 
Immature female Sprague-Dawley rats (Charles River Laboratories, Inc., Wilmington, MA, USA) were asphyxiated in a $\mathrm{CO}_{2}$ chamber and decapitated. Pituitaries were collected and cells were dispersed with $0 \cdot 4 \%$ porcine pancreatic trypsin dissociation medium as previously described, with modifications (Wilfinger et al. 1984, Krummen \& Baldwin 1988). Cells were plated in 24-well plates at the confluency of $5 \times 10^{4}$ cells per well. Cells were allowed to attach overnight and then treated with $30 \mathrm{ng} / \mathrm{ml}$ activin A or $10 \mathrm{ng} / \mathrm{ml} \mathrm{TGF} \beta 1$ in $\alpha$-MEM medium supplemented with $10 \%$ charcoal-stripped FBS and $1 \%$ antibiotic (Invitrogen). Media were collected after $24 \mathrm{~h}$ treatment and submitted for FSH radioimmunoassay (Ligand Assay and Analysis Core Laboratory, Center for Research in Reproduction, University of Virginia, Charlottesville, VA, USA). FSH was determined by RIA with NIH-FSH RP-2 (NIDDK) as standard and anti-rFSH (S-11) as primary antibody. The limit of detection in the assay was $0.7 \mathrm{ng} / \mathrm{ml}$ with less than $0.5 \%$ cross-reactivity with other pituitary hormones. Intact intra-assay variation was $3 \cdot 5 \%$ for the low control and $1.3 \%$ for the QCRS2 control. The average intra-assay and interassay coefficients of variation are from $8 \cdot 7$ to $14 \cdot 4 \%$ respectively.

\section{RT-PCR analysis}

Total RNA from L $\beta$ T2 cells and female mouse pituitaries was isolated using the TRIzol reagent (Invitrogen) and samples were treated with RQ1 RNase-free DNase (Promega, Madison, WI, USA) and phenol-chloroform extracted. RNA samples $(5 \mu \mathrm{g})$ were then primed with random hexamers and reverse transcribed with M-MLV reverse transcriptase (Promega) according to the manufacturer's instructions. The cDNA from the original RT reaction was subjected to PCR amplification for 35 cycles under the following conditions: $94{ }^{\circ} \mathrm{C}$ for $60 \mathrm{~s}, 54{ }^{\circ} \mathrm{C}$ for $60 \mathrm{~s}, 72{ }^{\circ} \mathrm{C}$ for $60 \mathrm{~s}$. Negative controls were run using water and RNA that had not been reverse transcribed with M-MLV. Primers used to amplify ligand-specific type I and type II receptors are presented in Table 1.

\section{Immunoblot analysis}

L $\beta$ T2 cells were plated in 6-well plates and transfected with $1 \mu \mathrm{g}$ empty vector or expression vector containing TGF $\beta$ type II receptor (T $\beta$ RII) cDNA, and were then treated for $1 \mathrm{~h}$ with control media, activin A $(30 \mathrm{ng} / \mathrm{ml})$ or TGF $\beta 1(10 \mathrm{ng} / \mathrm{ml})$. Cells were lysed in buffer containing $50 \mathrm{mM}$ Tris, $\mathrm{pH} 7 \cdot 5,10 \%$ glycerol, $5 \mathrm{mM}$ EDTA, $150 \mathrm{mM} \mathrm{NaCl}$ and $0.5 \% \mathrm{NP}-40$ and supplemented with Complete Mini Protease Inhibitor Cocktail tablets (Roche, Indianapolis, IN, USA) and Phosphatase Inhibitor Cocktail II (Sigma, St Louis, MO, USA). Samples were run under reduced conditions on NuPage
Table 1 PCR primers
Primer sequence

\begin{tabular}{ll}
\multirow{2}{*}{ Gene } & \\
ActRIIA & 5' ATGGGAGCTGCTGCAAAGTTG \\
& 3' GGTAGGCCATCTTGTGATGTCTGT \\
ActRIIB & 5' ATCTACTACAACGCCAACTGGGA \\
& 3' TGGCTCGTACGTGACTTCTGG \\
TßRII & 5' TGGCCGCTGCATATCGTC \\
& 3' GCATCTTCCAGAGTGAAGCCG \\
BMPRII & 5' ATGACTTCCTCGCTGCATCG \\
& 3' GCCTCCATCATGTTCATGCTG \\
ALK1 & 5' ATGACCTTGGGGAGCTTCAGA \\
& 3' GATGGGCATCAACTTCTGGCT \\
ALK2 & 5' TGGAGTAATGATCCTTCCTGTGC \\
& 3' TCTTACACGTCATCTTCCCCTG \\
ALK3 & 5' CATCAGATTACTGGGAGCCTGTCT \\
& 3' CCGACAACATTCTATTGTCCTGC \\
ALK4 & 5' CAGACCAACTACACCTGTGAGACAG \\
& 3' ATGATAAGGAAGAGGAGGAAGACG \\
ALK5 & 5' GTCCGCAGCTCCTCATCGT \\
& 3' GACAGTGCGGTTATGGCAGAT \\
ALK6 & 5' TGTCCGGAAGACTCAGTCAACA \\
& 3' CAGACAGTCACAGAGATAAGCAAGG \\
ALK7 & 5' CACTGAGCCTGGCCCTCC \\
& 3' TTGGCGATGCTGTGGGAA
\end{tabular}

Expected size (bp)

505

297

320,395

572

352

239

358

247

293

291
4-12\% Bis-Tris denaturing gels (Invitrogen) and transferred onto nitrocellulose. An immunoblot was performed using rabbit polyclonal antibodies. The phospho-Smad2 (3101) and phospho-Smad3/phosphoSmadl (9514) antibodies were acquired from Cell Signaling Technologies (Beverly, MA, USA) and actin antibody was purchased from Sigma. Goat anti-rabbit horseradish peroxidase-conjugated secondary antibody was obtained from Zymed Laboratories (San Francisco, CA, USA). For siRNA analysis, L $\beta$ T2 cells were plated in 24-well plates and co-transfected with $100 \mathrm{ng}$ of the indicated ALK or Smad expression vector and siRNA oligoduplexes for $24 \mathrm{~h}$. Cells were lysed and cell lysates were run on a NuPage $4-12 \%$ gel as described above. An immunoblot analysis was performed using rabbit anti-hemagluttin (Zymed), mouse anti-Flag or mouse anti-Myc (Sigma) antibodies. Immunoblot results were visualized using the ECL detection reagent (Amersham Biosciences, Piscataway, NJ, USA).

\section{Immunofluorescence}

Pituitary paraffin sections mounted on slides were washed in PBS and incubated with 10\% normal donkey serum (Jackson ImmunoResearch Laboratories, Inc., West Grove, PA, USA) in PBS $/ 0 \cdot 3 \%$ Triton X-100 (PBST) buffer for $1 \mathrm{~h}$ at room temperature. Sections were then incubated overnight at $4{ }^{\circ} \mathrm{C}$ with cocktails of affinity purified goat antihuman T $\beta$ RII IgG $(10 \mu \mathrm{g} / \mathrm{ml}$; $\mathrm{R} \& \mathrm{D}$ Biosystems) and rabbit antisera directed against rat 
A.

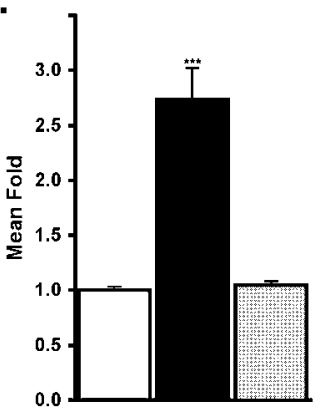

B.

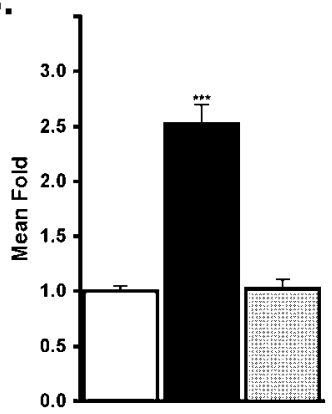

C.

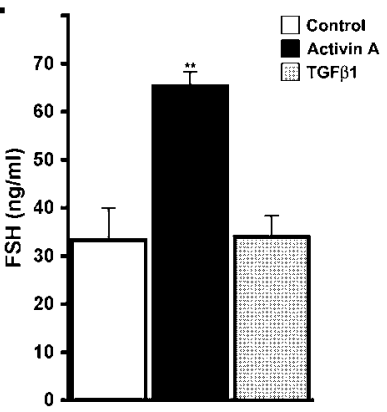

Figure 1 TGF $\beta$ does not stimulate FSH $\beta$ transcription and FSH secretion. L $\beta$ T2 cells were transiently transfected with $-338 \mathrm{rFSH} \beta$-Luc (A) or p3TP-Lux (B) promoter constructs and treated with control media, activin A (30 ng/ml) or TGF $\beta 1(10 \mathrm{ng} / \mathrm{ml})$ for $6 \mathrm{~h}$. Data are plotted as the mean fold increase of the ligand-stimulated promoter activity over untreated control \pm S.E.M. of three independent experiments, each performed in quadruplicate. (C) Dispersed rat pituitary cells were treated with control media, activin A (30 ng/ml) or TGF $\beta 1$ (10 ng/ml) for $24 \mathrm{~h}$ and FSH secretion was measured by radioimmunoassay. Hormone secretion is reported in $\mathrm{ng}$ per $\mathrm{ml}$ media and plotted as the mean \pm S.E.M. of $n=4$ samples. ${ }^{\star *} P<0.01,{ }^{* *} P<0.001$

FSH $\beta$, luteinizing hormone $\beta$ (LH $\beta$ ), prolactin or growth hormone (diluted 1:50 in PBST; NIDDK's National Hormone and Pituitary Program). Following three washes in PBS, tissues were incubated for $1 \mathrm{~h}$ at room temperature with Cy3-conjugated donkey antigoat IgG (1:400 in PBST) and FITG-conjugated donkey anti-rabbit IgG (both from Jackson ImmunoResearch Laboratories, Inc.). Slides were washed three times in PBS, briefly dried, mounted with Vectastain (Vector Laboratories, Inc., Burlingame, CA, USA) and sealed. Slides were viewed using fluorescence microscopy and digital images were collected at $40 \times$ magnification using a SpotRT monochrome digital camera (Diagnostic Instruments, Sterling Heights, MI, USA) and analyzed using the Metamorph image analysis system (v.4.5; Universal Imaging Corp., West Chester, PA, USA).

\section{Statistical analysis}

The values are expressed as the mean fold over control \pm S.E.M. Analysis of variance (ANOVA) followed by Tukey's post hoc test was used to evaluate differences between treatment groups. $P<0 \cdot 01$ and $P<0 \cdot 001$ were considered statistically significant.

\section{Results}

\section{Activin but not TGF $\beta$ induces FSH $\beta$ transcription and $\mathrm{FSH}$ secretion}

We have previously demonstrated that the intracellular signaling molecule Smad3 is involved in activinmediated stimulation of FSH $\beta$ gene transcription (Suszko et al. 2003, 2005). As both activin and TGF $\beta$ can induce Smad3 phosphorylation and nuclear translocation, we investigated whether TGF $\beta$ can, in a similar manner to activin, induce activity of the rat FSH $\beta$ promoter. The mouse gonadotrope-derived cell line, L $\beta$ T2, was transiently transfected with 338 base pairs of the 5 '-flanking region of rat $\mathrm{FSH} \beta$ gene fused to the luciferase reporter gene ( $-338 \mathrm{rFSH} \beta$-Luc) or to the plasminogen activator inhibitor-1 promoter ligated upstream of the luciferase reporter gene (p3TP-Lux) (Dennler et al. 1998). Cells were treated with control media, activin or TGF $\beta 1$ for $6 \mathrm{~h}$ and luciferase assays were performed. Transcriptional activity of both promoters was significantly stimulated by activin $(P<0 \cdot 001)$. However, neither promoter directed luciferase production in response to TGF $\beta$ (Fig. 1A,B).

To address whether the rat FSH $\beta$ promoter may lack elements necessary for TGF $\beta$ response, we investigated TGF $\beta$-mediated secretion of FSH in a primary pituitary cell system. Dispersed rat pituitary cells were treated with activin or TGF $\beta 1$ and FSH levels in the media were measured (Fig. 1C). Activin, but not TGF $\beta$, stimulated FSH secretion from the primary pituitary cells confirming the results of the transfection experiment.

\section{Constitutively active TGF $\beta$-specific type I receptor ALK5 stimulates FSH $\beta$ transcription}

Ligands of the TGF $\beta$ superfamily initiate the signaling cascade through binding to a specific type II serine/threonine kinase receptor, which complexes with and phosphorylates a type I receptor. We examined whether a TGFß-specific type I receptor, ALK5, can trigger molecular events leading to stimulation of the rat FSH $\beta$ promoter. L $\beta$ T2 cells were transiently co-transfected with the -338 rFSH $\beta$-Luc or p3TP-Lux 


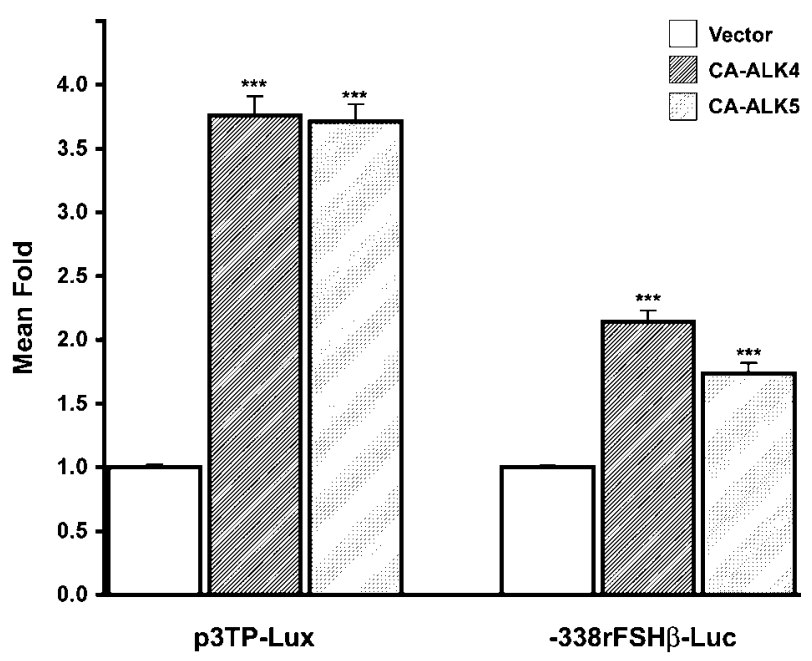

Figure 2 TGF $\beta$ pathway is inducible in the L $\beta T 2$ cell line. L $\beta T 2$ cells were transiently transfected with p3TP-Lux or -338 $\mathrm{rFSH} \beta$-Luc promoter constructs and empty vector or the indicated constitutively active type I (CA-ALK4 or CA-ALK5) receptor expression vectors. Data are plotted as the mean fold increase of the ALK-stimulated promoter activity over empty vector control \pm S.E.M. of at least $n=5$ independent experiments, each performed in quadruplicate. ${ }^{* *} P<0.001$, statistically significant stimulation compared with empty vector control.

reporter construct and with constitutively active activin or TGF $\beta$ type I receptor expression vectors (CA-ALK4 or CA-ALK5), and luciferase activity was measured (Fig. 2). As expected, p3TP promoter was highly responsive to overexpression of both ALK4 and ALK5 receptors. Interestingly, FSH $\beta$ was also significantly activated not only by ALK4 but also by the TGF $\beta$-specific ALK5 receptor. In fact, stimulation of this promoter by ALK4 reached $2 \cdot 1$-fold over empty vector control, whereas ALK5 induced transcription by up to $1 \cdot 7$-fold.

\section{Gonadotrope-derived cell line LßT2 and adult mouse pituitary gonadotrope cells lack T $\beta$ RII}

As constitutively active TGF $\beta$-specific type I receptor can induce FSH $\beta$ promoter activity in L $\beta$ T2 cells, we concluded that downstream components of the TGF $\beta$ ligand signaling are intact in these cells. Therefore, we examined the presence of receptors necessary for initiation of signaling cascades by TGF $\beta$ ligands in the LBT2 cell line (Fig. 3A,B). The presence of mRNA transcripts for both activin type II receptors, ActRIIA and ActRIIB, as well as for the BMP-specific type II receptor, BMPRII, was detected in these cells. Importantly, T $\beta$ RII mRNA was not detected in L $\beta$ T2 cells, although both transcript variants of this gene were found in the mouse pituitary. All mRNA transcripts of type I receptors of the TGF $\beta$ superfamily, including TGF $\beta$-specific ALK5, were detected in L $\beta$ T2 cells.
As T $\beta$ RII is absent in the gonadotrope-derived L $\beta$ T2 cell line, we examined whether this receptor is expressed in anterior pituitary, specifically in gonadotrope cells. Results of the immunofluorescence experiment show that T $\beta$ RII localizes to somatotrope and lactotrope cells of adult mouse pituitary (Fig. 3C). Yellow overlay that is produced by co-localization of the receptor and either prolactin or growth hormone (panels $\mathrm{c}$ and $\mathrm{d}$ ) is not present in cells immunoreactive for FSH $\beta$ and LH $\beta$ subunits (panels a and b). These data suggest that the absence of the TGF $\beta$ receptor from gonadotropes restricts TGF $\beta$ activity in this cell type and provides a mechanism of cell-specific ligand action. Consistent with our immunolocalization studies, the somato-lactotrope cell line, GH3, expresses T $\beta$ RII and is TGF $\beta$ responsive (Yamashita et al. 1995). As expected, the rat FSH $\beta$ promoter was not responsive to either activin or TGF $\beta$, whereas generic p3TP promoter was significantly induced by both ligands in these cells (data not shown).

\section{Rescue of TGF $\beta$-mediated stimulation of the rat FSH $\beta$ promoter by T $\beta B R I I$ overexpression}

As constitutively active ALK 5 was able to induce activity of the FSH $\beta$ promoter, we examined whether TGF $\beta$ stimulation of FSH $\beta$-subunit gene transcription requires a specific type II receptor. L $\beta$ T2 cells were cotransfected with the $-338 \mathrm{rFSH} \beta$-Luc or the p3TP-Lux reporter construct and T $\beta$ RII expression vector, and then treated for $6 \mathrm{~h}$ with activin or TGF $\beta 1$ (Fig. 4A). Co-transfection of the TGF $\beta$-specific receptor led to a $2 \cdot 7$-fold increase in the TGF $\beta$-stimulated p3TP promoter activity over untreated controls. The rat FSH $\beta$ promoter was also significantly stimulated (up to $2 \cdot 1$-fold) when treated with TGF $\beta 1$ in the presence of T $\beta$ RII.

We also examined the effects of T $\beta$ RII overexpression on activation of downstream signaling molecules, Smads. An immunoblot of lysates from L $\beta T 2$ cells overexpressing T $\beta$ RII shows increased phosphorylation of Smad proteins upon TGF $\beta 1$ treatment (Fig. 4B). Interestingly, in addition to activin and TGF $\beta$-specific Smad molecules (Smad2 and Smad3), BMP-specific Smad (Smad1) was activated with TGF $\beta 1$ treatments in the presence of T $\beta$ RII receptor.

\section{Specific type I receptors mediate activin- and TGF $\beta$-stimulated transcription of the FSH $\beta$ gene}

It is known that a high degree of crosstalk between receptors and signaling molecules exists within the TGF $\beta$ superfamily. To establish specificity of the activin and TGF $\beta$ pathways in the L $\beta$ T2 cell line, we used siRNA oligoduplexes to suppress expression of ALK4 and ALK5 proteins independently. First, to confirm the specificity of the siRNA duplexes, L $\beta$ T2 cells were 
co-transfected with HA-tagged ALK4 and ALK5 expression vectors and the indicated siRNA oligoduplexes. As expected, there was a selective downregulation of ALK protein expression with the introduction of ALK4- or ALK5-directed siRNA (Fig. 5A). As Smad3 is important for $\mathrm{FSH} \beta$ transcription we confirmed that ALK-specific siRNA had no effect on expression of this protein. Next, we examined whether downregulation of endogenous ALK proteins has an effect on activin and TGF $\beta$-mediated stimulation of FSH $\beta$ promoter. L $\beta$ T2 cells were co-transfected with the -338 rFSH $\beta$-Luc
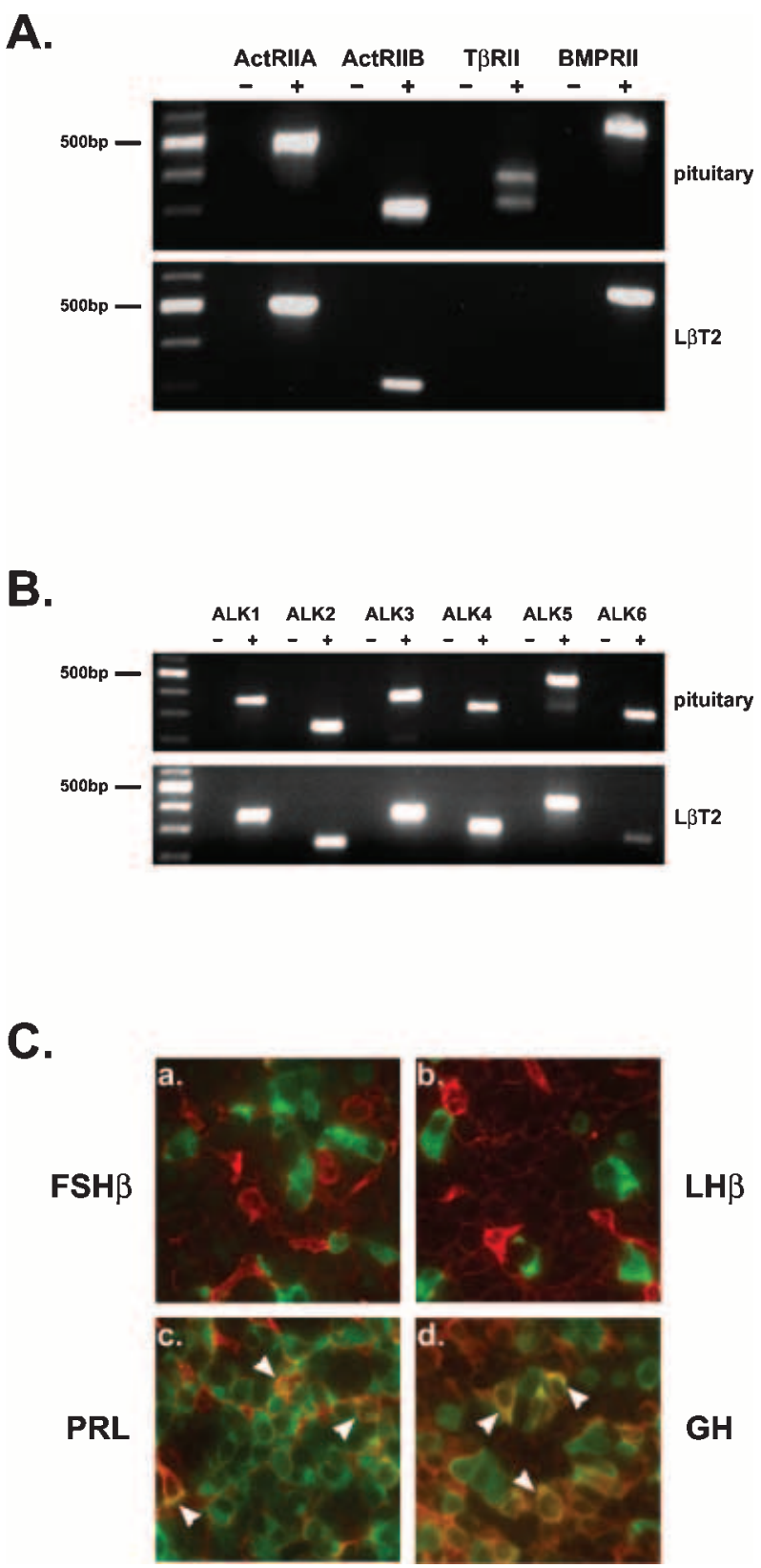

Journal of Molecular Endocrinology (2006) 36, 591-600 reporter construct and T $\beta$ RII expression vector, as well as control, ALK4- or ALK5-specific siRNA duplexes (Fig. 5B). The cells were then treated with control media, activin or TGF $\beta 1$ for $6 \mathrm{~h}$. The results of the luciferase assay show that downregulation of ALK4 reduced activin- and not TGF $\beta$-mediated induction of the FSH $\beta$ promoter. Likewise, ablation of ALK 5 protein expression caused a specific and significant decrease in stimulation of the promoter by TGF $\beta$ ligand. Similar results were observed with the $\mathrm{p} 3 \mathrm{TP}-\mathrm{Lux}$ promoter (data not shown). These data suggest that activin and TGF $\beta$ engage different receptor complexes in order to propagate specific signal transduction cascades.

\section{Smad3 mediates induction of the FSH $\beta$ promoter by TGF $\beta$ ligand}

We have previously demonstrated that Smad3 is necessary and sufficient for transcriptional regulation of the FSH $\beta$-subunit in L $\beta T 2$ cells (Suszko et al. 2003). Therefore, we wanted to investigate whether this cytoplasmic co-regulator is also involved in mediating the TGF $\beta$ response in our system. In addition, we have observed that in the presence of over-expressed T $\beta$ RII this ligand can stimulate phosphorylation of Smadl. Hence, we also examined whether this BMP-specific factor has any biological significance in the regulation of FSH $\beta$ gene transcription. To address these questions, we employed siRNA oligoduplexes to suppress expression of Smadl and Smad3 proteins independently. The specificity of the siRNA was confirmed by cotransfecting Smad expression vectors with the complementary siRNA oligoduplexes and examining protein abundance by immunoblot analysis of cell lysates. As expected, there was a selective downregulation of Smad protein expression with the introduction of specific siRNAs (Fig. 6A,B). Next, we examined whether downregulation of endogenous Smad proteins has an effect on activin and TGF $\beta$-mediated stimulation of FSH $\beta$ promoter. L $\beta$ T2 cells were co-transfected with

Figure 3 TGF $\beta$ type II receptor is not expressed in the L $\beta$ T2 cell line and it does not localize to gonadotrope cells of the anterior pituitary. $L \beta T 2$ and mouse pituitary mRNA were reversely transcribed to cDNA. (A) Specific primer pairs were used to amplify cDNA of activin (ActRIIA and ActRIIB), TGF $\beta$ (T $\beta$ RII) and BMP (BMPRII) type II receptors. (B) cDNA of type I receptors (ALK) for the TGF $\beta$ ligands were amplified. PCR products were resolved on a $2 \%$ agarose gel. (-) indicates negative control with no reverse transcriptase enzyme and $(+)$ shows the RT-PCR product of appropriate size. (C) Mouse pituitary sections were co-incubated with antibodies specific to $\mathrm{FSH} \beta(\mathrm{a}), \mathrm{LH} \beta(\mathrm{b})$, prolactin (PRL; c) or growth hormone $(\mathrm{GH}$; d) and TGF $\beta$ type II receptor protein. Immunoreactive signal was detected by immunofluorescence using FITC-conjugated anti-rabbit and Cy3-conjugated anti-goat secondary antibodies. Pictures were taken at $40 \times$ magnification. Overlay of FITC and Cy3 signals is colored yellow and indicated by arrowheads. 
A.

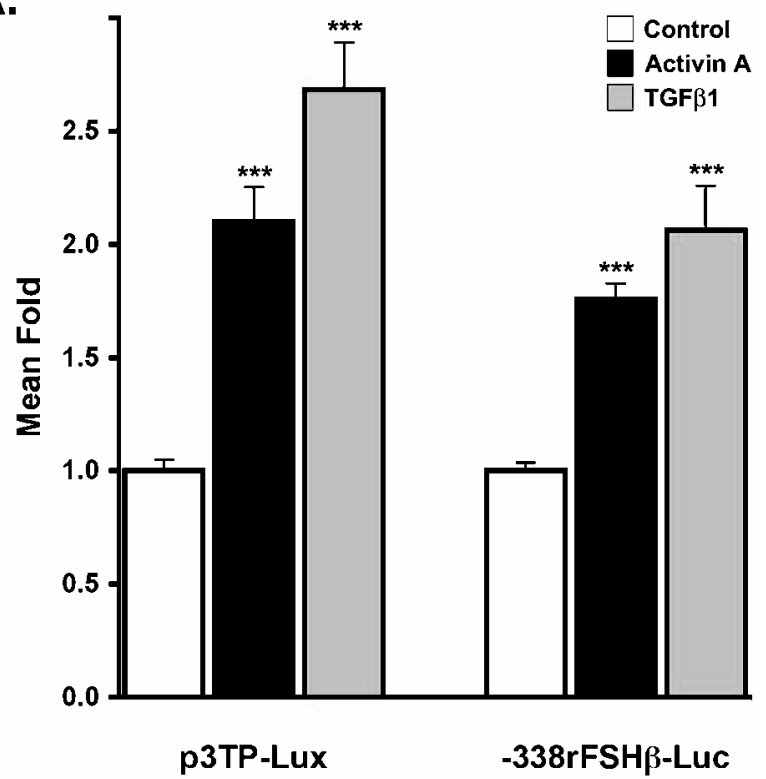

A.

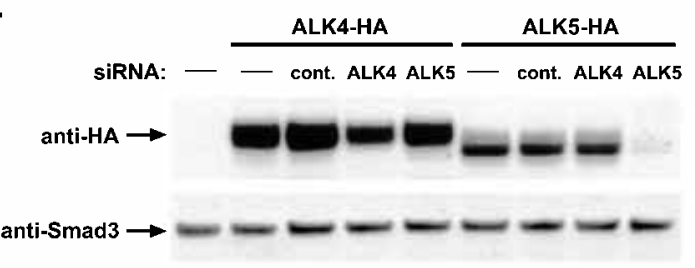

B.

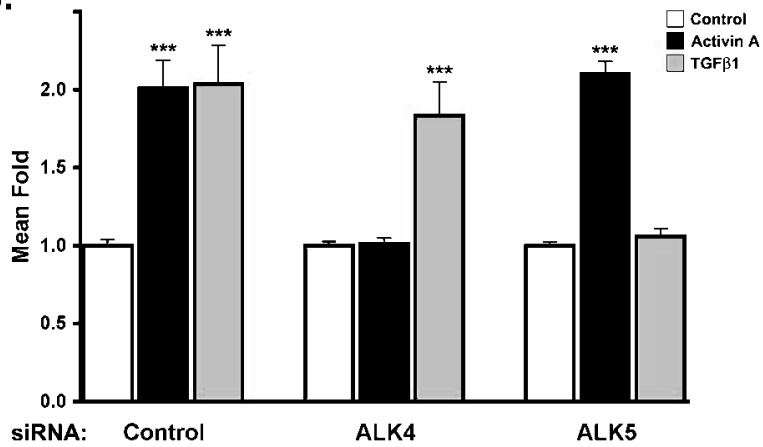

Figure 5 ALK5 mediates the TGF $\beta$ pathway in the L $\beta$ T2 cell line. L $\beta$ T2 cells were transfected with HA-tagged type I (ALK4 or ALK5) receptor expression vectors and the indicated SiRNA oligoduplexes. Expression of ALK proteins was evaluated by the immunoblot using polyclonal anti-HA antibody. cont., control. (B) L $\beta T 2$ cells were transiently transfected with -338 rFSH $\beta$-Luc promoter construct, T $\beta$ RII expression vector and the indicated control or type I receptor (ALK4 or ALK5) siRNA oligoduplexes. Cells were treated with control media, activin A or TGF $\beta 1$ for $6 \mathrm{~h}$ and luciferase assay was performed. Data are plotted as the mean fold increase of the ligand-stimulated promoter activity over untreated control \pm S.E.M. of four independent experiments, each performed in quadruplicate. ${ }^{* \star \star} P<0.001$, statistically significant difference between treatment groups and untreated control.

$6 \mathrm{~h}$. As expected, downregulation of Smad3 reduced both activin- and TGF $\beta$-mediated induction of the FSH $\beta$ promoter. In contrast, decreased Smadl protein expression had no significant effects on the promoter activity of either ligand. Similar results were observed with the p3TP-Lux promoter (data not shown). Taken together, these results suggest that Smad3, and not Smad1, mediates TGF $\beta$-dependent FSH $\beta$ gene transcription in L $\beta$ T2 cells.

\section{Discussion}

Progression of the female reproductive cycle depends on synchronized and repetitive synthesis and secretion of a variety of hormones. The gonadotropin hormones, FSH and LH, are integral components of the female the $-338 \mathrm{rFSH} \beta$-Luc reporter construct and T $\beta$ RII expression vector, as well as control, Smadl- or Smad3-specific siRNA duplexes (Fig. 6C). The cells were then treated with control media, activin or TGF $\beta 1$ for 
A.

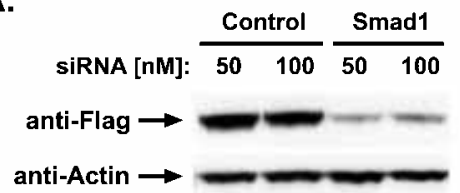

B.

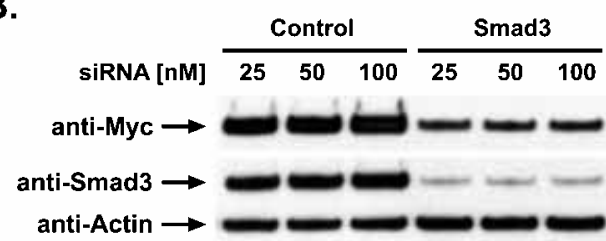

C.

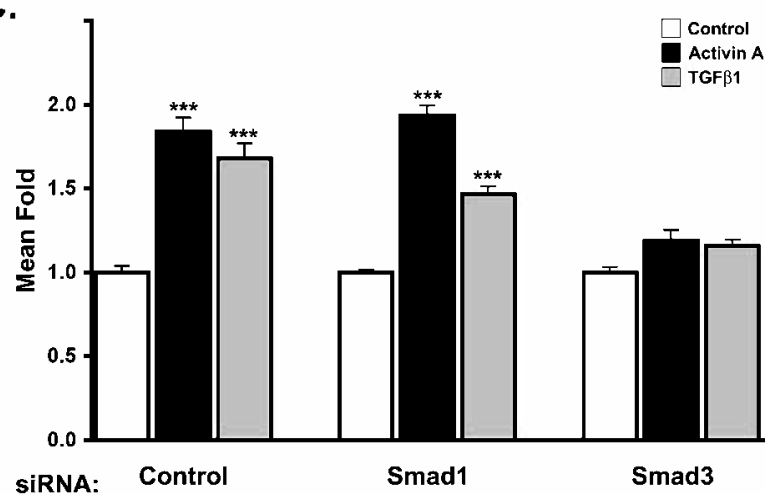

Figure 6 Smad3 is involved in TGF $\beta$-mediated activation of the FSH $\beta$ promoter. L $\beta$ T2 cells were transfected with Flag-tagged Smad1 (A) or Myc-tagged Smad3 (B) expression vectors and increasing amounts of Smad-specific siRNA oligoduplexes. Expression of Smad proteins was evaluated by immunoblot using monoclonal anti-Flag or anti-Myc antibody respectively.

(C) L $\beta T 2$ cells were transiently transfected with -338

rFSH $\beta$-Luc promoter construct, T $\beta$ RII expression vector and the indicated control, Smad1 or Smad3 siRNA oligoduplexes. Cells were treated with control media, activin A or TGF $\beta 1$ for $6 \mathrm{~h}$. Data are plotted as the mean fold increase of the ligand-stimulated promoter activity over untreated control \pm S.E.M. of three independent experiments, each performed in quadruplicate. ${ }^{* * *} P<0.001$, statistically significant difference between treatment groups and untreated control.

reproductive axis and require specific cues from ovarian steroid and peptide hormones, as well as pituitary and hypothalamic regulatory factors. Both hormones are secreted by gonadotropes of the anterior pituitary and play important roles in follicular development. Structurally, the gonadotropins share an $\alpha$-subunit ( $\alpha \mathrm{GSU}$ ), which is common to all members of the pituitary glycoprotein family, while the $\beta$-subunit is distinctive to each member. Activin is a major regulator of FSH, which targets FSH through transcriptional regulation of the unique FSH $\beta$-subunit (Carroll et al. 1989, Weiss et al. 1995). Previous work demonstrated that activin stimulates FSH $\beta$ gene transcription directly and this regulation involves a proximal promoter region that binds both Smad3 and Smad4 proteins (Suszko et al. 2003, Gregory et al. 2005).

The limited number of receptors and intracellular Smad molecules that are available for transducing TGF $\beta$ signals suggests that there are mechanisms by which a cell, such as a gonadotrope, manages different hormonal inputs and confers cell type-specific responses. In fact, activin affects the expression of many genes but activin-regulated FSH biosynthesis is exclusive to pituitary gonadotropes. One way by which cells achieve specificity of ligand action is through transcriptional co-regulators. A number of tissue- and cell-specific transcription factors were identified, including the pituitary-specific members of the bicoid-related homeodomain proteins, Pitx1 and Pitx2, which permit the cell type-restricted FSH response (Zakaria et al. 2002, Suszko et al. 2003). However, given that members of the TGF $\beta$ superfamily can activate the same transduction pathways and that any cell can potentially respond to these signals, it is still a puzzle as to how the pituitary gonadotropes respond specifically to activin, and not to TGF $\beta$, by producing FSH.

In our model gonadotrope-derived cell line, TGF $\beta$ does not induce FSH $\beta$ promoter transcription. We have established that TGF $\beta$ type II is not expressed in the L $\beta$ T2 lineage, which explains the lack of TGF $\beta$ response in these cells. Indeed, overexpression of T $\beta$ RII confers some degree of TGF $\beta$ responsiveness to the rat FSH $\beta$ promoter. Thus, one mechanism by which the gonadotrope controls its responses to TGF $\beta$ ligands is through the complement of expressed receptors. This is, in fact, the basis for specificity of many endocrinology and reproductive systems. For example, only ovarian granulosa cells can respond to FSH because only these cell express FSH receptor.

Although TGF $\beta$ and activin signals are initiated by different receptor complexes, these ligands share a set of intracellular mediators, Smad2 and Smad3. Smad3 has been shown to be important for activinmediated transactivation of the FSH $\beta$ promoter (Suszko et al. 2003, Gregory et al. 2005). As expected, T $\beta$ RII overexpression in L $\beta$ T2 cells permitted TGF $\beta$-mediated phosphorylation of Smad proteins. Interestingly, in addition to Smad2 and Smad3, Smad1 was also phosphorylated in the presence of the T $\beta$ RII. However, downregulation of Smadl protein expression by specific siRNA oligoduplexes had no effect on TGF $\beta$-mediated stimulation of FSH $\beta$ gene. Whereas it is possible that Smadl can mediate other responses to TGF $\beta$ ligand in L $\beta$ T2 cells, this factor is not necessary for 
TGF $\beta$-mediated FSH $\beta$ gene regulation. In fact, the siRNA results suggest that $\operatorname{Smad} 3$ is important for mediating the TGF $\beta$ signal that leads to FSH $\beta$ transcription. These data suggest that the gonadotrope cell cannot discriminate between Smad3 phosphorylated via the activin and the TGF $\beta$ pathways and it responds to this signaling molecule in a similar manner. Intracellular signals initiated by TGF $\beta$ were able to stimulate FSH $\beta$ promoter activity suggesting that availability, assembly and activation of a specific receptor complex, rather than specificity of intracellular mediators, is necessary for a proper gonadotrope response to the extarcellular ligand.

Regulation of the specific pathway through bioavailability of ligands and receptors is not entirely a new concept. In mammary tissue, for example, activin signaling components are found during mid to late lactation and then decrease during involution, while TGF $\beta$ levels are low during lactation to restrict hyperproliferation of the tissue (Jeruss et al. 2003). Also, temporal expression of activin and TGF $\beta$ signaling components is observed throughout follicular development. Expression of activin receptors is significantly more abundant in the early stages of follicles, while the presence of TRRII is restricted to the granulosa cells of antral follicles (Bristol \& Woodruff 2004). Similarly, in our gonadotrope cell model, the lack of T $\beta R I I$ expression provides a mechanism of cell-restricted responses. This established system of available receptors may be necessary for normal function of the cell and any disturbance of this network may lead to abnormal gene regulation. Indeed, upregulation of activin type II receptor (ActRIIB) expression is prevalent in pituitary adenomas as compared with normal pituitary tissue (Alexander et al. 1996).

It is obvious that ligands of the TGF $\beta$ superfamily confer wide biological responses in different biological contexts. As the pituitary gonadotrope cells are sensitive to activin and not to TGF $\beta$ ligand, the question arises regarding the physiological relevance of such restricted FSH $\beta$ stimulation. One explanation lies in the negative control of activin action by the potent antagonist, inhibin. Inhibin is an endocrine hormone that is produced in a cycle-dependent manner by the ovary to provide a negative feedback directly at the level of the pituitary. Structurally, inhibin shares a $\beta$-subunit with activin and blocks activin signaling by forming an inactive complex with its receptors (Lewis et al. 2000, Chapman \& Woodruff 2001). Although, inhibin has been shown to modestly antagonize TGF $\beta$ signaling (Wiater \& Vale 2003), its primary role is to block activin. Thus the necessary positive and negative inputs exist for a dynamic regulation of the pituitary hormone synthesis and release. If TGF $\beta$ was permitted to regulate FSH even at low levels, reproductive health could be significantly compromised. Therefore, it is necessary for the pituitary gonadotrope to be able to respond only to a particular ligand in a very precise manner in order to control both specific hormone stimulation and downregulation.

In conclusion, the results of these studies reveal a level of regulated cellular responses in the pituitary gonadotrope that may be important for normal reproductive function. These data suggest that receptor bioavailability can dictate specificity of TGF $\beta$ action in pituitary gonadotrope cells. More importantly, these results reveal that the gonadotrope cells are unable to discriminate between intracellular signaling pathways initiated by different TGF $\beta$ ligands. We predict receptor assembly as well as their activation and desensitization are important mechanisms in this and other systems that require filtering, integrating and discriminating various hormonal signals.

\section{Acknowledgements}

The authors are grateful to Dr U Kaiser and Dr J Massagué who kindly provided the full-length rat FSH $\beta$ and p3TP-Lux promoter constructs respectively. Constitutively active ALK plasmids were generous gifts of Dr Y Chen. Additional thanks go to Dr A F Parlow and the NIDDK National Hormone and Peptide Program for the FSH $\beta$, LH $\beta$, prolactin and growth hormone antisera. We would also like to credit the University of Virginia Center for Research in Reproduction Ligand Assay and Analysis Core (NICHD (SCCPRR) Grant U54-HD28934) for performing the FSH radioimmunoassay. Finally, our sincerest thanks to Dr M Antenos for invaluable help in preparing this manuscript.

This work was supported by NIH grant HD044464 (to T K W). During part of this study M I S was a Fellow of the Training Program in Reproductive Biology (HD00768). The authors declare that there is no conflict of interest that would prejudice the impartiality of this scientific work.

\section{References}

Alexander JM, Bikkal HA, Zervas NT, Laws ER Jr \& Klibanski A 1996 Tumor-specific expression and alternate splicing of messenger ribonucleic acid encoding activin/transforming growth factor-beta receptors in human pituitary adenomas. Fournal of Clinical Endocrinology and Metabolism 81 783-790.

Bernard DJ, Chapman SC \& Woodruff TK 2001 An emerging role for co-receptors in inhibin signal transduction. Molecular and Cellular Endocrinology 180 55-62.

Bristol SK \& Woodruff TK 2004 Follicle-restricted compartmentalization of transforming growth factor beta superfamily ligands in the feline ovary. Biology of Reproduction $\mathbf{7 0}$ 846-859.

Carroll RS, Corrigan AZ, Gharib SD, Vale W \& Chin WW 1989 Inhibin, activin, and follistatin: regulation of follicle-stimulating 
hormone messenger ribonucleic acid levels. Molecular Endocrinology 3 1969-1976.

Chapman SC \& Woodruff TK 2001 Modulation of activin signal transduction by inhibin B and inhibin-binding protein (INhBP). Molecular Endocrinology 15 668-679.

Chen Y, Bhushan A \& Vale W 1997 Smad8 mediates the signaling of the ALK-2 [corrected] receptor serine kinase [published erratum appears in PNAS 199895 1968]. PNAS 94 12938-12943.

Dennler S, Itoh S, Vivien D, ten Dijke P, Huet S \& Gauthier JM 1998 Direct binding of Smad3 and Smad4 to critical TGF beta-inducible elements in the promoter of human plasminogen activator inhibitor-type 1 gene. EMBO fournal 17 3091-3100.

Gregory SJ, Lacza CT, Detz AA, Xu S, Petrillo LA \& Kaiser UB 2005 Synergy between activin A and GnRH in transcriptional activation of the rat follicle-stimulating hormone beta (FSH $\beta$ ) gene. Molecular Endocrinology 19 237-254.

Gurdon JB \& Bourillot PY 2001 Morphogen gradient interpretation. Nature 413 797-803.

Jeruss JS, Santiago JY \& Woodruff TK 2003 Localization of activin and inhibin subunits, receptors and SMADs in the mouse mammary gland. Molecular and Cellular Endocrinology 203 185-196.

Krummen LA \& Baldwin DM 1988 Regulation of luteinizing hormone subunit biosynthesis in cultured male anterior pituitary cells: effects of gonadotropin-releasing hormone and testosterone. Endocrinology 123 1868-1878.

Lewis KA, Gray PC, Blount AL, MacConell LA, Wiater E, Bilezikjian LM \& Vale W 2000 Betaglycan binds inhibin and can mediate functional antagonism of activin signalling. Nature $\mathbf{4 0 4}$ $411-414$.

Lu Z, Murray JT, Luo W, Li H, Wu X, Xu H, Backer JM \& Chen YG 2002 Transforming growth factor beta activates Smad2 in the absence of receptor endocytosis. Fournal of Biological Chemistry 277 29363-29368.

Nagarajan RP \& Chen Y 2000 Structural basis for the functional difference between Smad2 and Smad3 in FAST-2 (forkhead activin signal transducer-2)-mediated transcription. Biochemical fournal 350 253-259.

Pangas SA \& Woodruff TK 2002 Production and purification of recombinant human inhibin and activin. Fournal of Endocrinology $172199-210$.
Razani B, Zhang XL, Bitzer M, von Gersdorff G, Bottinger EP \& Lisanti MP 2001 Caveolin-1 regulates transforming growth factor (TGF)-beta/SMAD signaling through an interaction with the TGF-beta type I receptor. Fournal of Biological Chemistry 276 $6727-6738$

Shi Y \& Massague J 2003 Mechanisms of TGF-beta signaling from cell membrane to the nucleus. Cell 113 685-700.

Suszko MI, Lo DJ, Suh H, Camper SA \& Woodruff TK 2003 Regulation of the rat follicle-stimulating hormone beta-subunit promoter by activin. Molecular Endocrinology 17 318-332.

Suszko MI, Balkin DM, Chen Y \& Woodruff TK 2005 Smad3 mediates activin-induced transcription of follicle-stimulating hormone $\beta$-subunit gene. Molecular Endocrinology 19 1849-1858.

Weiss J, Guendner MJ, Halvorson LM \& Jameson JL 1995 Transcriptional activation of the follicle-stimulating hormone beta-subunit gene by activin. Endocrinology 136 1885-1891.

Wiater E \& Vale W 2003 Inhibin is an antagonist of bone morphogenetic protein signaling. Fournal of Biological Chemistry 278 7934-7941.

Wilfinger WW, Larsen WJ, Downs TR \& Wilbur DL 1984 An in vitro model for studies of intercellular communication in cultured rat anterior pituitary cells. Tissue Cell 16 483-497.

Yamashita H, Okadome T, Franzen P, ten Dijke P, Heldin CH \& Miyazono K 1995 A rat pituitary tumor cell line (GH3) expresses type I and type II receptors and other cell surface binding protein(s) for transforming growth factor-beta. Fournal of Biological Chemistry 270 770-774.

Zakaria MM, Jeong KH, Lacza C \& Kaiser UB 2002 Pituitary homeobox 1 activates the rat FSH beta (rFSHbeta) gene through both direct and indirect interactions with the rFSHbeta gene promoter. Molecular Endocrinology 16 1840-1852.

Zwijsen A, Verschueren K \& Huylebroeck D 2003 New intracellular components of bone morphogenetic protein/Smad signaling cascades. FEBS Letters 546 133-139.

Received in final form 24 January 2006 Accepted 15 February 2006 